\section{Performance of New Banana Germplasm in South Florida}

\author{
Randy C. Ploetz, Jody L. Haynes, Aimé Vázquez, and David Benscher \\ University of Florida, Institute of Food and Agricultural Sciences, Tropical \\ Research and Education Center, 18905 SW 280th Street, Homestead, \\ FL 33031-3314
}

Additional index words. banana bunchy top virus, banana streak virus, cucumber mosaic virus, Fusarium oxysporum f. sp. cubense, fusarium wilt, productivity index, organoleptic fruit quality, Panama disease, virus indexing, Musa spp.

\begin{abstract}
In 1995, 37 new dessert and cooking bananas (Musa spp.) were introduced into South Florida for evaluation under local edaphic and environmental conditions. The number of pseudostems per mat, height at fruiting, and cycling time were determined during the first fruiting cycle, and bunch number and bunch weight were recorded from 1996 to 1998. A productivity index (PIX), calculated as $100 \times$ mean bunch weight in $\mathrm{kg} /$ cycling time in days, was used to determine the productivity of the clones over time. Informal taste panels assessed the appearance and organoleptic qualities of fruit on a subjective 1 to 4 scale. In a separate experiment, the susceptibility of 30 of the clones to fusarium wilt, caused by Fusarium oxysporum f. sp. cubense, was assessed. Some of the most popular and productive clones were susceptible to fusarium wilt and are not recommended for production in areas that have a history of this disease. The dessert clones 'Pisang Ceylan', FHIA01', FHIA02', and FHIA17' and the cooking accessions 'Kandrian', 'Kumunamba', and 'Saba' resisted fusarium wilt, produced moderate to high yields (PIXs $\geq 1$ ) of good to excellent fruit (mean ratings $\geq 3$ ), and are recommended for use in all areas in Florida.
\end{abstract}

Banana has been an important tropical fruit crop in Florida for over a century (Stambaugh, 1952). Production occurred initially as far north as Jacksonville $\left(30^{\circ} \mathrm{N}\right)$, and profits from some operations were said to have financed a few of the first large citrus plantations in the state. Commercial production is now consolidated in southeastern Miami-Dade County $\left(25.5^{\circ} \mathrm{N}\right)$. In 1997 , an estimated 140 of the 141 ha of banana in the state were in this county, which produced fruit valued at $>\$ 2.5$ million per annum (Crane, 1997; Degner et al., 1997).

Despite the history and importance of banana in Florida, the crop is poorly adapted to conditions in the state. It grows best in deep, well-drained alluvial soils, has fairly demanding nutritional requirements, and does not tolerate cold temperatures (Stover and

Received for publication 11 Mar. 1999. Accepted for publication 18 June 1999. We thank Dr. JeanPierre Horry, germplasm officer for the International Network for the Improvement of Banana and Plantain (INIBAP) in Montpellier, France, and Ms. Ines Van Den Houwe, officer-in-charge of the INIBAP International Transit Center (ITC) in Lueven, Belgium, for supplying much of the germplasm in Table 1 . We are also grateful to Dr. Mike Smith and Ms. Sharon Hamill of the Queensland Dept. of Primary Industry (QDPI), Maroochy, Australia, for donating some of the accessions and for supplying high-quality plantlets for this study. We acknowledge the technical assistance of Zaragoza Alegria and Ozvany Rodriguez. This work was funded partially by grants from the Florida Dept. of Agriculture. This is Florida Agricultural Experiment Station Journal Series No.R-06831.The cost of publishing this paper was defrayed in part by the payment of page charges. Under postal regulations, this paper therefore must be hereby marked advertisement solely to indicate this fact.
Simmonds, 1987). Thus, conditions in Miami-Dade County are less than optimum. Winter temperatures are frequently low enough to damage plants or reduce their growth, and severely damages banana leaves. Although leaf tearing reduces leaf temperature in the Musaceae (Taylor and Sexton, 1972), water loss from such leaves can be substantial (Brun, 1961). Agricultural soils in the area are usually alkaline, shallow, and nutritionally deficient, and are very low in organic matter and cation exchange capacity (Noble et al., 1996). Finally, a lethal disease, fusarium wilt, is widespread in the area and has had a considerable impact on production (Ploetz and Shepard, 1989).

Prior to the mid-1990s, there were $\approx 60$ different banana cultivars in Miami-Dade (Don and Katy Chapin, personal communication). However, only four of these, 'Bluggoe' (known locally as 'Burro' or 'Orinoco'), 'Hua Moa' ('Hawaiiano'), 'Mysore', and 'Silk' ('Manzano'), were important.

Each of the above cultivars is deficient. 'Bluggoe', 'Hua Moa', and 'Silk' are susceptible to fusarium wilt. The disease has essentially eliminated production of 'Silk' in the county, and is beginning to impact the production of 'Bluggoe' and 'Hua Moa'. 'Hua Moa' is also very cold-sensitive, and is affected by a postharvest finger rot, caused by Lasiodiplodia theobromae (Pat.) Griffon \& Maubl., and a yield-decline phenomenon that may be caused by the spiral nematode, Helicotylenchus multicinctus (Cobb) Golden (Ploetz, unpublished). Although 'Mysore' is a hardy banana that possesses good resistance to fusarium wilt, clones of the cultivar in South Florida are infected with banana streak virus (BSV). high wind during the winter and early spring
Campbell and Popenoe (1971) categorized 24 different banana cultivars based upon their ease of care and productivity in South Florida. Their report represents the only prior evaluation of banana germplasm in Florida. The objectives of the current project were to: 1) introduce new banana accessions to South Florida, 2) evaluate their adaptability to local soils and winter conditions, and 3 ) assess their productivity and the quality of their fruit. Ancillary work to determine the resistance of the accessions to fusarium wilt is described in another paper (Ploetz et al., 1999), but is summarized below.

\section{Materials and Methods}

Of the 37 dessert and cooking cultivars selected for evaluation (Table 1), 32 were from the in vitro collection of the International Transit Center (ITC) at the Katholieke Universiteit in Leuven, Belgium. Each of these accessions was indexed for the three most important Musa viruses, banana bunchy top virus, cucumber mosaic virus, and banana streak virus. Notably, the 'Mysore' accession included in these studies, 'Pisang Ceylon', is the only accession of this cultivar that is known to be free of banana streak virus. The five remaining accessions were from the in vitro collection of the Queensland Dept. of Primary Industry (QDPI) in Maroochy, Australia.

All accessions were multiplied via standard meristem tissue culture in Dr. Mike Smith's QDPI laboratory in Maroochy. In Fall 1995, the micropropagated germplasm was shipped, with Australian phytosanitary certification and under APHIS permit, from QDPI to the Univ. of Florida's Tropical Research and Education Center in Homestead (TREC). Plantlets were grown in 3.8-L polybags filled with potting mix (Reliable Peat, Miami) prior to use in the field.

Two accessions, 'Niyarma yik' and 'Rimina', a Fe'i banana, were cold-sensitive and were killed in a shadehouse prior to the initiation of field experiments during Winter 1995-96. On 20 May 1996, the 35 remaining accessions were planted in a completely randomized design in a field at TREC. Each accession was replicated seven times; replicates consisted of pairs of plants. Rows were planted on raised beds, $\approx 0.2 \mathrm{~m}$ in height, that were aligned from east to west and $4.5 \mathrm{~m}$ apart. Within rows, plants were separated by $2.5 \mathrm{~m}$. Bi-weekly irrigation and fertilization practices for banana in the area were followed for the duration of the experiment (I. Ganessingh, personal communication).

Beginning 4 months after planting, suckering and height of the accessions were recorded monthly. The number of suckers that were produced in a mat and height at fruiting (distance in meters from the base of the stem to the top of the peduncle) were determined for each accession at the end of the first fruiting cycle. Cycling time (the number of days elapsed between planting and harvest) was also recorded for the first fruiting cycle, and bunch weight (weight in $\mathrm{kg}$ of all hands in a bunch without the raceme) was recorded from 1996 
Table 1. Cultivar, genome, and accession codes for new banana accessions and the experiments in which they were included.

\begin{tabular}{|c|c|c|c|c|c|c|}
\hline & & $\operatorname{Accession}(\mathrm{s})^{\mathrm{z}}$ & & & & \\
\hline Cultivar ${ }^{\mathrm{y}}$ & Genome $^{\mathrm{x}}$ & $\overline{\text { ITC/QDPI/PNG }}$ & Usage $^{w}$ & Origin & Synonyms & Affinities ${ }^{\mathrm{v}}$, attributes \\
\hline Niyarma yik & AA & $0477 / 563$ & $\mathrm{D}$ & & & banksii \\
\hline Pamoti on & AA & $1229 / 576 /---$ & $\mathrm{D}$ & Philippines & & banksii \\
\hline Pisang jari buaya & AA & 0312/577/--- & $\mathrm{D}$ & Malaysia & & $\begin{array}{l}\text { Used as parent in FHIA breeding } \\
\text { program }\end{array}$ \\
\hline Pisang lemak manis & AA & 1183/578/--- & $\mathrm{D}$ & Malaysia (Philippines) & & \\
\hline Pisang mas & AA & 0653/579/--- & $\mathrm{D}$ & Malaysia & 'Datil', 'Sucrier' & Wide distribution; very sweet fruit \\
\hline Rose & AA & 0712/574/--- & $\mathrm{D}$ & Indonesia & & $\begin{array}{l}\text { Aromatic; cold sensitive; used in } \\
\text { CIRAD-FHLOR breeding program }\end{array}$ \\
\hline Señorita & AA & 1230/580/--- & $\mathrm{D}$ & Philippines & & microcarpa \\
\hline Veinte cohol & AA & $1031 / 582 /---$ & $\mathrm{D}$ & Philippines & & microcarpa \\
\hline Kunnan & $\mathrm{AB}$ & 1034/583/--- & $\mathrm{D}$ & India & & Ney poovan subgroup \\
\hline Ney poovan & $\mathrm{AB}$ & ---/398/--- & $\mathrm{D}$ & Honduras (India) & & \\
\hline Ney poovan & $\mathrm{AB}$ & 0459/584/--- & $\mathrm{D}$ & Australia (India) & & \\
\hline Inarnibal & AAA & 0477/563/--- & $\mathrm{D}$ & Philippines (Honduras) & 'Pisang Berlin' & microcarpa \\
\hline Pisang nangka & AAA & 1062/585/--- & $\mathrm{D}$ & Malaysia & & $\begin{array}{l}\text { An AA and an } \mathrm{AAB} \text { clone exist with } \\
\text { the same name }\end{array}$ \\
\hline Williams & AAA & 0570/587/--- & $\mathrm{D}$ & Southeast Asia & 'Giant Cavendish' & $\begin{array}{l}\text { Cavendish subgroup; wide } \\
\text { distribution }\end{array}$ \\
\hline Yangambi km5 & AAA & 1123/586/--- & $\mathrm{D}$ & Congo & & $\begin{array}{l}\text { Ibota subgroup; interesting } \\
\text { pineapple-like flavor }\end{array}$ \\
\hline Kofi & $\mathrm{AAB}$ & $0912 / 355 / 310$ & $\mathrm{D}$ & Papua New Guinea & & Iholena subgroup \\
\hline Kumunamba & $\mathrm{AAB}$ & $0824 / 337 / 195$ & $\mathrm{D}$ & Papua New Guinea & 'Yamunamba' & Iholena subgroup \\
\hline Pisang Ceylon & AAB & 0650/589/--- & $\mathrm{D}$ & Sri Lanka & 'Mysore' & $\begin{array}{l}\text { Only 'Mysore' accession free of } \\
\text { BSV }\end{array}$ \\
\hline Popoulu & $\mathrm{AAB}$ & 0335/588/--- & $\mathrm{C}$ & Polynesia & & Maia Maoli subgroup \\
\hline Prata anã & $\mathrm{AAB}$ & 0962/590/--- & $\mathrm{D}$ & Brazil & & Pome subgroup \\
\hline Silk (sport) & $\mathrm{AAB}$ & 1222/591/--- & $\mathrm{D}$ & Tanzania & 'Apple', 'Manzano' & Wide distribution \\
\hline Sugar & $\mathrm{AAB}$ & ---/404/--- & $\mathrm{D}$ & Australia & 'Silk' & Wide distribution \\
\hline Walha & $\mathrm{AAB}$ & 1033/592/--- & $\mathrm{D}$ & India & 'Rajapuri’' & Pome subgroup \\
\hline Bluggoe & $\mathrm{ABB}$ & ---/261/--- & $\mathrm{C}$ & Australia (India) & 'Chato', 'Moko' & Wide distribution \\
\hline Ducasse & $\mathrm{ABB}$ & $---/ 256 /---$ & $\mathrm{D}, \mathrm{C}$ & Australia & 'Pisang awak' & Very hardy cultivar \\
\hline Dwarf kalapua & $\mathrm{ABB}$ & $0812 / 368 / 171$ & $\mathrm{C}$ & Papua New Guinea & & \\
\hline Kluai namwa khom & $\mathrm{ABB}$ & 0526/593/--- & $\mathrm{D}, \mathrm{C}$ & Thailand & dwarf 'Pisang awak' & \\
\hline Kandrian & $\mathrm{ABB}$ & $0803 / 367 / 148$ & $\mathrm{C}$ & Papua New Guinea & & Vigorous \\
\hline Pelipita & $\mathrm{ABB}$ & 0472/564/--- & $\mathrm{C}$ & Honduras (Philippines) & 'Pelipia' & Resistant to Moko disease \\
\hline Pelipita & $\mathrm{ABB}$ & ---/595/--- & $\mathrm{C}$ & Australia (Philippines) & 'Pelipia' & Resistant to Moko disease \\
\hline Saba & $\mathrm{ABB}$ & 1138/594/--- & $\mathrm{C}$ & Guadeloupe (Philippines) & & \\
\hline FHIA02 & AAAA & 0505/597/--- & $\mathrm{D}$ & Honduras & 'Mona Lisa' & $\begin{array}{l}\text { Synthetic hybrid; marketed as } \\
\text { "pestcide-free" banana in Canada }\end{array}$ \\
\hline FHIA17 & AAAA & 1264/599/--- & $\mathrm{D}$ & Honduras & & Synthetic hybrid \\
\hline FHIA23 & AAAA & 1265/600/--- & $\mathrm{D}$ & Honduras & & Synthetic hybrid \\
\hline FHIA01 & AAAB & 0504/596/--- & $\mathrm{D}$ & Honduras & 'Goldfinger' & $\begin{array}{l}\text { Synthetic hybrid; one of first bred } \\
\text { bananas to be widely deployed }\end{array}$ \\
\hline FHIA03 & $\mathrm{AABB}$ & 0506/598/--- & $\mathrm{C}$ & Honduras & & $\begin{array}{l}\text { Synthetic hybrid; one of first bred } \\
\text { bananas to be widely deployed }\end{array}$ \\
\hline Rimina & --- & 1010/---/201 & $\mathrm{C}$ & Papua New Guinea & & $\begin{array}{l}\text { Fe'i banana; extremely sensitive to } \\
\text { cold temperatures }\end{array}$ \\
\hline
\end{tabular}

${ }^{2}$ Accession codes are, in order, those for: the International Transit Center (ITC) in Lueven, Belgium; the Queensland Dept. of Primary Industries (QDPI) in Maroochy, Australia; and germplasm obtained during a Musa collecting mission in Papua New Guinea (PNG) that was sponsored by the International Board for Plant Genetic Resources (IBPGR, now known as IPGRI).

${ }^{y}$ Cultivars' names are those given by the original donor. FHIA prefix denotes a product of the breeding program of the Fundación Hondureña de Investigación Agrícola in La Lima, Honduras.

${ }^{x}$ Genome: A and B refer to the haploid contributions of Musa acuminata Colla and M. balbisiana Colla to diploid, triploid, and tetraploid cultivars (Simmonds and Shepherd, 1955).

wUsage: $\mathrm{D}=$ dessert and $\mathrm{C}=$ cooking.

'Affinities: banksii = derivative of Musa acuminata ssp. banksii; microcarpa = derivative of $M$. acuminata ssp. microcarpa. CIRAD-FLHOR = Centre de coopération internationale en recherche agronomique pour le développement-Département des productions fruitères et horticoles, Guadeloupe.

to 1998. Informal taste panels at TREC and at agricultural festivals in Homestead and West Palm Beach evaluated the appearance and organoleptic qualities of fruit from the experiment. Subjective 1-4 scales were used for both parameters where: $1=$ poor, $2=$ fair, $3=$ good, and $4=$ excellent. Ratings were computed from 743 evaluations by $>200$ testers.

To determine a clone's yield potential, a productivity index (PIX) was computed as:

$$
\text { PIX }=100 \times \frac{\mathrm{BW}}{\mathrm{CT}}
$$

where $\mathrm{BW}=$ bunch weight in $\mathrm{kg}$ and $\mathrm{CT}=$ cycling time in days.

Data were analyzed statistically with the GLM procedure of SAS for PCs. Mean separations for bunch weight and PIX were conducted only for clones for which at least four bunches were harvested, and statistical analyses of fruit taste and appearance were conducted for those accessions for which a total of 10 or more evaluations were available.

\section{Results}

Mean suckering rate per mat ranged from 3.6 to 11.6 during the first fruiting cycle (Table
2). Suckering generally decreased as the ploidy of clones increased, with diploids exhibiting a significantly higher rate than triploids or tetraploids (respectively, 7.34 vs. 5.56 and 4.82; $P<0.05$; data not shown). No obvious relationship was observed between genome and suckering rate.

Height at fruiting and cycling time also varied significantly among the clones. 'Kandrian' was $\approx 2 \mathrm{~m}$ taller than the shortest clones, and cycling time varied from $372 \mathrm{~d}$ for 'Kumunamba' to $826 \mathrm{~d}$ for 'Kandrian' (Table 2 ). Neither trait was significantly correlated with ploidy or genome (data not shown). 
Table 2. Mean growth characteristics of new accessions of banana

\begin{tabular}{lccc}
\hline Cultivar $^{\mathrm{z}}$ & Pseudostems/mat & Height at fruiting $^{\mathrm{y}}$ & Cycling time (d) $^{\mathrm{x}}$ \\
\hline Pamoti on & $9.0 \mathrm{~b}^{\mathrm{w}}$ & $2.8 \mathrm{j}-\mathrm{l}$ & $521 \mathrm{e}-\mathrm{i}$ \\
Pisang jari buaya & $5.8 \mathrm{e}-\mathrm{g}$ & $3.2 \mathrm{f}-\mathrm{k}$ & $720 \mathrm{~b}$ \\
Pisang lemak manis & $7.9 \mathrm{c}-\mathrm{d}$ & $2.9 \mathrm{~h}-\mathrm{l}$ & $541 \mathrm{~d}-\mathrm{i}$ \\
Pisang mas & $5.7 \mathrm{e}-\mathrm{h}$ & $3.3 \mathrm{~d}-\mathrm{j}$ & $610 \mathrm{~b}-\mathrm{f}$ \\
Rose & $11.6 \mathrm{a}$ & $2.9 \mathrm{~h}-\mathrm{l}$ & nd $^{\mathrm{v}}$ \\
Señorita & $6.2 \mathrm{e}-\mathrm{f}$ & $2.7 \mathrm{j}-\mathrm{l}$ & $495 \mathrm{f}-\mathrm{i}$ \\
Veinte cohol & $5.1 \mathrm{f}-\mathrm{i}$ & $2.6 \mathrm{l}$ & $548 \mathrm{~d}-\mathrm{i}$ \\
Inarnibal & $5.3 \mathrm{e}-\mathrm{i}$ & $3.1 \mathrm{~g}-1$ & $653 \mathrm{~b}-\mathrm{d}$ \\
Pisang nangka & $5.4 \mathrm{e}-\mathrm{i}$ & $3.3 \mathrm{~d}-\mathrm{j}$ & $573 \mathrm{c}-\mathrm{g}$ \\
Williams & $4.9 \mathrm{~g}-\mathrm{j}$ & $1.3 \mathrm{~m}$ & $472 \mathrm{~g}-\mathrm{i}$ \\
Yangambi km5 & $8.9 \mathrm{~b}$ & $2.9 \mathrm{i}-\mathrm{l}$ & $637 \mathrm{~b}-\mathrm{e}$ \\
Kofi & $5.3 \mathrm{e}-\mathrm{i}$ & $3.3 \mathrm{~d}-\mathrm{j}$ & $502 \mathrm{f}-\mathrm{i}$ \\
Kumunamba & $3.6 \mathrm{k}$ & $3.8 \mathrm{~b}-\mathrm{c}$ & $372 \mathrm{j}$ \\
Pisang ceylan & $6.3 \mathrm{e}-\mathrm{i}$ & $3.8 \mathrm{~b}-\mathrm{d}$ & $616 \mathrm{~b}-\mathrm{f}$ \\
Popoulu & $5.2 \mathrm{e}-\mathrm{i}$ & $3.2 \mathrm{e}-\mathrm{k}$ & $427 \mathrm{i}-\mathrm{j}$ \\
Prata anã & $4.0 \mathrm{j}-\mathrm{k}$ & $3.3 \mathrm{~d}-\mathrm{j}$ & $442 \mathrm{i}-\mathrm{j}$ \\
Silk (sport) & $4.6 \mathrm{~h}-\mathrm{k}$ & $3.3 \mathrm{e}-\mathrm{f}$ & $519 \mathrm{e}-\mathrm{I}$ \\
Sugar & $4.9 \mathrm{~g}-\mathrm{j}$ & $3.4 \mathrm{c}-\mathrm{i}$ & $573 \mathrm{c}-\mathrm{g}$ \\
Kunnan & $8.5 \mathrm{~b}-\mathrm{c}$ & $3.2 \mathrm{e}-\mathrm{k}$ & $516 \mathrm{e}-\mathrm{I}$ \\
Ney poovan 398 & $5.9 \mathrm{e}-\mathrm{g}$ & $3.5 \mathrm{c}-\mathrm{h}$ & $451 \mathrm{~g}-\mathrm{I}$ \\
Ney poovan 584 & $7.7 \mathrm{c}-\mathrm{d}$ & $3.6 \mathrm{~b}-\mathrm{g}$ & $426 \mathrm{i}-\mathrm{j}$ \\
Bluggoe & $7.4 \mathrm{~d}$ & $3.8 \mathrm{~b}-\mathrm{e}$ & $538 \mathrm{~d}-\mathrm{i}$ \\
Ducasse & $5.4 \mathrm{e}-\mathrm{i}$ & $3.9 \mathrm{~b}-\mathrm{c}$ & $562 \mathrm{~d}-\mathrm{h}$ \\
Dwarf kalapua & $4.9 \mathrm{~g}-\mathrm{j}$ & $2.8 \mathrm{j}-\mathrm{l}$ & $548 \mathrm{~d}-\mathrm{i}$ \\
Kandrian & $5.0 \mathrm{~g}-\mathrm{j}$ & $4.5 \mathrm{a}$ & $826 \mathrm{a}$ \\
Kluai namwa khom & $5.4 \mathrm{e}-\mathrm{i}$ & 2.71 & $514 \mathrm{e}-\mathrm{i}$ \\
Pelipita 564 & $6.0 \mathrm{e}-\mathrm{g}$ & $3.7 \mathrm{~b}-\mathrm{f}$ & $520 \mathrm{e}-\mathrm{i}$ \\
Pelipita 595 & $6.3 \mathrm{e}$ & $4.0 \mathrm{~b}$ & $513 \mathrm{e}-\mathrm{i}$ \\
Saba & $6.2 \mathrm{e}-\mathrm{f}$ & $3.9 \mathrm{~b}-\mathrm{c}$ & $506 \mathrm{f}-\mathrm{i}$ \\
FHIA01 & $5.4 \mathrm{e}-\mathrm{i}$ & $3.2 \mathrm{e}-\mathrm{k}$ & $500 \mathrm{f}-\mathrm{i}$ \\
FHIA02 & $4.4 \mathrm{j}-\mathrm{k}$ & $3.2 \mathrm{f}-\mathrm{k}$ & $525 \mathrm{e}-\mathrm{i}$ \\
FHIA03 & $3.6 \mathrm{k}$ & $3.6 \mathrm{~b}-\mathrm{g}$ & $453 \mathrm{~g}-\mathrm{i}$ \\
FHIA17 & $5.1 \mathrm{f}-\mathrm{i}$ & $3.2 \mathrm{f}-\mathrm{k}$ & $690 \mathrm{~b}-\mathrm{c}$ \\
FHIA23 & $5.6 \mathrm{e}-\mathrm{h}$ & $3.4 \mathrm{c}-\mathrm{i}$ & $716 \mathrm{~b}$ \\
\hline Cut & &
\end{tabular}

${ }^{2}$ Cultivar genome, source, and synonyms are listed in Table 1 .

${ }^{y}$ Height in meters from base of plant to top of peduncle.

${ }^{x}$ Days from planting to first fruit harvest.

"Mean separation within columns by Duncan's multiple range test, $P \leq 0.05$.

${ }^{v}$ nd $=$ not determined.

Bunch weight was highly correlated with accession, ploidy and genome, ranged from $0.8 \mathrm{~kg}$ for 'Pisang mas' to $14.4 \mathrm{~kg}$ for 'Kandrian', and was significantly lower for diploids than for triploids and tetraploids (Table 3 and data not shown).

Productivity indices ranged from 0.1 for 'Pisang mas' to 2.7 for 'Popoulu' (Table 3). Twenty-two clones had PIXs $>1$, an arbitrary level of acceptable productivity in this study. No diploid AA accession approached this level, whereas triploids had higher, but not significantly different $(P \leq 0.05)$, mean indices than tetraploids (respectively, 1.27 vs. 1.2).

Eleven of 20 cooking clones had mean ratings of 3 or higher (good to excellent), of which 'Kofi' rated highest (3.8; Table 3). Sixteen dessert clones had mean taste ratings of 3 or higher, and 11 of these had a mean appearance rating of 3 or greater. Statistical analyses of the taste and appearance data were conducted for 21 of the dessert cultivars for which a total of 10 or more evaluations were made (no cooking clone met the latter criterion). Of these, the 398 accession of 'Ney poovan' from QDPI had the highest taste rating, 3.79, although this was not significantly different from the rating for 12 other accessions.
Florida is less robust and produces smaller fruits and bunches than do 'Silk' clones in the FHIA collection (personal communication, Franklin Rosales).

Several of the ABB clones are also new to the United States. 'Kluai namwa khom' from Thailand is a dwarf 'Pisang awak' that will probably withstand high winds better than the larger 'Pisang awak'. 'Saba' and 'Pelipita' are excellent cooking bananas from the Philippines which have received little exposure in Miami-Dade County. 'Pelipita' is also resistant to Moko disease, caused by Ralstonia (Pseudomonas) solanacearum.

Finally, the FHIA hybrids, all of which are tetraploids, are vigorous plants that will probably find increased uses in South Florida's suboptimal growing situations; FHIA02, FHIA17, and FHIA23 had not been evaluated before in the United States. Importantly, the FHIA hybrids are generally resistant to fusarium wilt, the burrowing nematode, Radopholus similis (Cobb) Thorne, and black and yellow Sigatoka (caused by, respectively, Mycosphaerella fijiensis Morelet and $M$. musicola J.L. Mulder in J.L. Mulder \& Stover). Since black Sigatoka was found recently in South Florida (Ploetz and Mourichon, 1999), resistance to this destructive disease may soon assume greater importance in local production areas.

Banana is a tropical crop with low tolerance of cold temperatures (Stover and Simmonds, 1987). Three freezes occurred in Homestead during Winter 1995-96. At the time, the introduced germplasm was housed in a nonheated shadehouse where temperatures fell to a minimum of $2{ }^{\circ} \mathrm{C}$. Four of the accessions, 'Niyarma yik', 'Pisang mas', 'Yangambi km 5', and 'Rimina', were severely damaged, and 'Niyarma yik' and 'Rimina' eventually died. 'Rimina' is a Fe' $i$ banana and is coldsensitive. Campbell and Popenoe (1971) reported that another Fe'ibanana, 'Afara', would not survive most winters in South Florida. Although 'Pisang mas' is also known to be cold-sensitive, to our knowledge, the sensitivity of 'Niyarma yik' and' Yangambi km 5' had not been reported previously.

Tissue-cultured banana germplasm can develop somaclonal mutants during micropropagation (Stover, 1987). Many of these mutations are deleterious and are not evident until plants mature. In the present study, two somaclonal problems were observed. One plantlet of 'Pisang jari buaya' was a color chimera that was identified at planting, but fruit production did not appear to be affected. In contrast, all plantlets of the 'Williams' accession were dwarf off-types. In general, these plants were at least $50 \%$ shorter than normal 'Williams' and produced smaller than normal bunches and fingers (Table 2). Since the 'Williams' accession was not true-to-type, it was excluded from the analysis of relationships between ploidy and genome and the traits above.

The inverse relationship between suckering rate and increased ploidy was observed previously by Vakili (1967). Autotetraploids of Musa balbisiana Colla produced fewer suck- 
ers than did the diploid parent. Although Vakili (1967) also noted that the tetraploids were taller, ploidy was not related to the stature of accessions in the current study.

Several of the tested clones had an AA genome. All shared the genome's fruit characteristics of thin fruit skin and sweet flesh, and four, 'Pamoti on', 'Pisang lemak manis', 'Veinte cohol', and 'Señorita', originated in the Philippines, a country with a great diversity of AA dessert bananas (Pascua, 1990). Unfortunately, none of the AA clones in this study was very productive, corroborating previous conclusions about the poor performance of AA clones (Stover and Simmonds, 1987). Twenty-two of 33 accessions had PIXs $>1$, but no AA accession approached this level of productivity. Interestingly, both accessions of 'Ney poovan', an AB diploid, had PIXs of 1.2 and 1.4 that approached or exceeded ratings for many triploids and tetraploids in the study (Table 3).

Fruit taste and appearance evaluations were conducted throughout 1997 and 1998. To ensure that the evaluations adequately reflected the characteristics of fruit the clone would produce over the range of weather conditions it would encounter in South Florida, only 21 accessions, which were evaluated at least 10 times over the 2 -year period, were statistically analyzed (Table 3 ). Of the 21 dessert clones that were evaluated at least 10 times, $13 \mathrm{had}$ mean ratings that were identical, statistically, to the highest rated clone, 'Ney poovan' 398 (mean $=3.79$ ). 'Pisang mas' had a perfect score of 4, but was evaluated only six times.

Most of the accessions displayed at least one meritorious characteristic. However, only seven dessert and eight cooking clones produced reasonably high yields of acceptable fruit (PIXs of 1 or higher and 3 or higher in taste tests) (Table 4). Unfortunately, three of the dessert clones, 'Ney poovan' 398, 'Ney poovan' 584, and 'Silk' (sport), and three of the cooking clones, 'Popoulu', 'Bluggoe', and 'Kluai namwa khom', that met these standards were susceptible to fusarium wilt (Ploetz et al., 1999). Another acceptable clone, 'Pelipita' 595 , was not tested, but is probably susceptible, since another accession of the cultivar, 'Pelipita' 564, did succumb during the screening trials (Ploetz et al., 1999). These clones are not recommended for production in areas that have a history of fusarium wilt, but could be used in other areas. Certainly, the excellent flavor of 'Ney poovan' 398 and outstanding productivity of 'Popoulu' suggest that these clones could become commercially important in South Florida despite their major flaw of susceptibility.

Another acceptable clone, 'Kofi', was not evaluated in the fusarium wilt trials, so its susceptibility is not known. The remaining accessions in Table 4 are resistant to fusarium wilt, and appear to have potential in all production areas in Miami-Dade County. The dessert clones 'Pisang Ceylon', 'FHIA01', 'FHIA02', and 'FHIA17', and the cooking clones 'Kumunamba', 'Kandrian' and 'Saba', are recommended for use in all areas in South Florida.
Table 3.Yield characteristics of new accessions of banana.

\begin{tabular}{|c|c|c|c|c|c|c|}
\hline \multirow[b]{2}{*}{ Cultivar $^{2}$} & \multirow{2}{*}{$\begin{array}{c}\text { No. bunches } \\
\text { harvested }\end{array}$} & \multirow{2}{*}{$\begin{array}{c}\text { Mean bunch } \\
\text { wt (kg) }\end{array}$} & \multirow{2}{*}{$\begin{array}{c}\text { Productivity } \\
\text { index }^{\mathrm{y}}\end{array}$} & \multicolumn{2}{|c|}{ Dessert } & \multirow{2}{*}{$\begin{array}{c}\text { Cooking } \\
\text { taste }\end{array}$} \\
\hline & & & & Appearance & Taste & \\
\hline Pamoti on & 29 & $1.7 \mathrm{j}^{\mathrm{x}}$ & $0.2 \mathrm{j}$ & 2.50 & 3.50 & $n d^{\mathrm{w}}$ \\
\hline Pisang jari buaya & 6 & $3.9 \mathrm{f}-\mathrm{j}$ & $0.6 \mathrm{~g}-\mathrm{j}$ & 1.63 & 2.00 & nd \\
\hline Pisang lemak manis & 22 & $3.2 \mathrm{~g}-\mathrm{j}$ & $0.3 \mathrm{i}-\mathrm{j}$ & 2.75 & 3.67 & nd \\
\hline Pisang mas & 4 & 0.8 & $0.1 \mathrm{j}$ & 2.00 & 4.00 & 2.00 \\
\hline Rose & 1 & 5.9 & nd & nd & nd & nd \\
\hline Señorita & 4 & 3.8 & $0.7 \mathrm{f}-\mathrm{i}$ & $3.35 \mathrm{a}$ & $3.54 \mathrm{a}-\mathrm{b}$ & nd \\
\hline Veinte cohol & 24 & $2.6 \mathrm{~h}-\mathrm{j}$ & $0.3 \mathrm{i}-\mathrm{j}$ & $2.15 \mathrm{~d}-\mathrm{e}$ & $2.25 \mathrm{e}-\mathrm{f}$ & 1.50 \\
\hline Inarnibal & 12 & $6.3 \mathrm{c}-\mathrm{g}$ & $1.0 \mathrm{e}-\mathrm{h}$ & 2.50 & 2.50 & nd \\
\hline Pisang nangka & 16 & $8.6 \mathrm{c}-\mathrm{e}$ & $1.4 \mathrm{~d}-\mathrm{e}$ & 2.15 & 1.50 & 2.00 \\
\hline Williams & 12 & $1.3 \mathrm{j}$ & $0.3 \mathrm{i}-\mathrm{j}$ & nd & nd & nd \\
\hline Yangambi km5 & 11 & $2.0 \mathrm{i}-\mathrm{j}$ & $0.3 \mathrm{i}-\mathrm{j}$ & $3.17 \mathrm{a}-\mathrm{b}$ & $3.33 \mathrm{a}-\mathrm{c}$ & nd \\
\hline Kofi & 12 & $8.8 \mathrm{c}-\mathrm{e}$ & $1.1 \mathrm{e}-\mathrm{h}$ & nd & 3.00 & 3.80 \\
\hline Kumunamba & 40 & $9.5 b-d$ & $1.5 \mathrm{~d}-\mathrm{e}$ & $2.91 \mathrm{a}-\mathrm{c}$ & $2.27 \mathrm{e}-\mathrm{f}$ & 3.67 \\
\hline Pisang ceylan & 24 & $7.0 \mathrm{c}-\mathrm{g}$ & $1.0 \mathrm{e}-\mathrm{h}$ & $2.94 \mathrm{a}-\mathrm{c}$ & $3.11 \mathrm{a}-\mathrm{d}$ & nd \\
\hline Popoulu & 25 & $12.8 \mathrm{a}-\mathrm{b}$ & $2.7 \mathrm{a}$ & $3.10 \mathrm{a}-\mathrm{b}$ & $2.98 \mathrm{a}-\mathrm{e}$ & 3.33 \\
\hline Prata anã & 23 & $7.3 \mathrm{c}-\mathrm{f}$ & $1.1 \mathrm{~d}-\mathrm{f}$ & $2.72 \mathrm{a}-\mathrm{e}$ & $2.99 \mathrm{a}-\mathrm{e}$ & 3.00 \\
\hline Silk (sport) & 27 & $6.0 \mathrm{~d}-\mathrm{h}$ & $1.0 \mathrm{e}-\mathrm{h}$ & $2.33 \mathrm{c}-\mathrm{e}$ & $3.29 \mathrm{a}-\mathrm{c}$ & nd \\
\hline Sugar & 9 & $4.3 \mathrm{f}-\mathrm{j}$ & $0.8 \mathrm{f}-\mathrm{i}$ & $2.50 \mathrm{~b}-\mathrm{e}$ & $2.67 \mathrm{c}-\mathrm{f}$ & 3.00 \\
\hline Walha & 1 & 5.5 & nd & nd & nd & nd \\
\hline Kunnan & 22 & $4.1 \mathrm{f}-\mathrm{j}$ & $0.6 \mathrm{~g}-\mathrm{j}$ & $2.44 \mathrm{~b}-\mathrm{e}$ & $2.31 \mathrm{~d}-\mathrm{f}$ & 2.00 \\
\hline Ney poovan 398 & 39 & $5.7 \mathrm{~d}-\mathrm{h}$ & $1.2 \mathrm{~d}-\mathrm{f}$ & $3.38 \mathrm{a}$ & $3.79 \mathrm{a}$ & nd \\
\hline Ney poovan 584 & 49 & $6.3 \mathrm{c}-\mathrm{h}$ & $1.4 \mathrm{~d}-\mathrm{e}$ & $3.07 \mathrm{a}-\mathrm{c}$ & $3.05 \mathrm{a}-\mathrm{e}$ & nd \\
\hline Bluggoe & 42 & $8.2 \mathrm{c}-\mathrm{e}$ & $1.4 \mathrm{~d}-\mathrm{e}$ & $2.67 \mathrm{a}-\mathrm{e}$ & $2.00 \mathrm{f}$ & 3.40 \\
\hline Ducasse & 24 & $6.6 \mathrm{c}-\mathrm{g}$ & $1.0 \mathrm{e}-\mathrm{h}$ & $2.78 \mathrm{a}-\mathrm{e}$ & $2.91 \mathrm{~b}-\mathrm{e}$ & nd \\
\hline Dwarf kalapua & 39 & $6.4 \mathrm{c}-\mathrm{g}$ & $1.0 \mathrm{e}-\mathrm{h}$ & $2.10 \mathrm{e}$ & $1.93 \mathrm{f}$ & 2.45 \\
\hline Kandrian & 7 & $14.4 \mathrm{a}$ & $2.0 \mathrm{~b}$ & 3.00 & 3.00 & 3.33 \\
\hline Kluai namwa khom & 27 & $8.6 \mathrm{c}-\mathrm{e}$ & $1.0 \mathrm{e}-\mathrm{h}$ & $2.63 \mathrm{a}-\mathrm{e}$ & $2.89 \mathrm{~b}-\mathrm{e}$ & 3.00 \\
\hline Pelipita 564 & 18 & $7.4 \mathrm{c}-\mathrm{f}$ & $1.3 \mathrm{~d}-\mathrm{e}$ & 1.00 & 1.50 & 2.50 \\
\hline Pelipita 595 & 16 & $6.4 \mathrm{c}-\mathrm{g}$ & $1.3 \mathrm{~d}-\mathrm{e}$ & 2.00 & 2.00 & 3.00 \\
\hline Saba & 50 & $10.1 \mathrm{~b}-\mathrm{c}$ & $1.9 \mathrm{~b}-\mathrm{c}$ & $2.86 \mathrm{a}-\mathrm{d}$ & $3.13 \mathrm{a}-\mathrm{d}$ & 3.43 \\
\hline FHIA01 & 28 & $8.9 \mathrm{c}-\mathrm{e}$ & $1.3 \mathrm{~d}-\mathrm{e}$ & $3.11 \mathrm{a}-\mathrm{b}$ & $3.19 \mathrm{a}-\mathrm{c}$ & 2.50 \\
\hline FHIA02 & 25 & $7.2 \mathrm{c}-\mathrm{f}$ & $1.1 \mathrm{~d}-\mathrm{g}$ & $3.08 \mathrm{a}-\mathrm{c}$ & $3.07 \mathrm{a}-\mathrm{e}$ & 2.00 \\
\hline FHIA03 & 24 & $8.9 \mathrm{c}-\mathrm{e}$ & $1.6 \mathrm{~b}-\mathrm{d}$ & $3.08 \mathrm{a}-\mathrm{c}$ & $3.00 \mathrm{a}-\mathrm{e}$ & 2.75 \\
\hline FHIA17 & 16 & $9.9 \mathrm{~b}-\mathrm{c}$ & $1.3 \mathrm{~d}-\mathrm{e}$ & $3.14 \mathrm{a}-\mathrm{b}$ & $3.29 \mathrm{a}-\mathrm{c}$ & 3.00 \\
\hline FHIA23 & 10 & $7.4 \mathrm{c}-\mathrm{f}$ & $0.7 \mathrm{f}-\mathrm{i}$ & 4.00 & 3.50 & nd \\
\hline
\end{tabular}

${ }^{\mathrm{z}}$ Cultivar genome, source, and synonyms are given in Table 1.

${ }^{\text {y} P r o d u c t i v i t y ~ i n d e x ~}=100 \times$ bunch weight/cycling time.

${ }^{x}$ Mean separation within columns by Duncan's multiple range test, $P \leq 0.05$. Cultivars for which four or fewer bunches were harvested or 10 or fewer taste evaluations were made were not analyzed. ${ }^{\mathrm{w}}$ nd $=$ no data.
Table 4. Summary of acceptability, yield performance, and susceptibility to fusarium wilt of the highest rated accessions of banana. ${ }^{\mathrm{z}}$

\begin{tabular}{lcccc}
\hline \hline & \multicolumn{2}{c}{ Taste } & Productivity & $\begin{array}{c}\text { Susceptible to } \\
\text { Cultivar }\end{array}$ \\
\cline { 2 - 3 } fusarium wilt?
\end{tabular}

${ }^{2}$ Only clones with mean taste ratings of 3 or higher and productivity indices of 1 or higher are included in this table.

${ }^{y}$ Susceptibility is based on results reported in Ploetz et al. (1999). Since 'Pelipita' 564 was susceptible in field screenings, 'Pelipita' 595 may also be susceptible.

'Saba' and 'FHIA17' are usually used as, respectively, cooking and dessert clones. 


\section{Literature Cited}

Arnaud, E. and J.P. Horry. (eds.) 1997. Musalogue: A catalogue of Musa germplasm. Papua New Guinea collecting missions, 1988-1989. Intl. Network for the Improvement of Banana and Plantain, Montpellier, France.

Brun, W.A. 1961. Photosynthesis and transpiration from upper and lower surfaces of intact banana leaves. Plant Physiol. 36:399-405.

Campbell, C.W. and J. Popenoe. 1971. Performance of edible banana cultivars in Florida. Proc. Trop. Reg. Amer. Soc. Hort. Sci. 15:26-30.

Crane, J.H. 1997. Tropical fruit crops acreage in Florida. Univ. of Florida, Trop. Res. and Educ. Ctr., Homestead.

Degner, R.L., S.D. Moss, and W.D. Mulkey. 1997. Economic impact of agriculture and agribusiness in Dade County, Florida. FAMRC Ind. Rpt. 971. Florida Agr. Mkt. Res. Ctr., Food and Resource
Econ. Dept., Univ. of Florida, IFAS, Gainesville. Noble, C.V., R.W. Drew, and J.D. Slabaugh. 1996. Soil survey of Dade County area, Florida. U.S. Dept. Agr., Natural Resources and Conserv. Serv. Pascua, O.C. 1990. A tentative key to Philippine bananas, p. 67-75. In: R.L. Jarret (ed.) Identification of genetic diversity in the genus Musa. Intl. Network for the Improvement of Banana and Plantain, Montpellier, France.

Ploetz, R.C., J.L. Haynes, and A. Vázquez. 1999. Responses of new banana accessions in South Florida to Panama disease. Crop Protection 18:445-449.

Ploetz, R.C. and X. Mourichon. 1999. First report of black Sigatoka in Florida. Plant Dis. 83:300.

Ploetz, R.C. and E.S. Shepard. 1989. Fusarial wilt of banana in Florida. Mycol. Res. 93:242-245.

Sharrock, S. 1990. Collecting Musa in Papua New Guinea, p. 140-157. In: R.L. Jarret (ed.). Identification of genetic diversity in the genus Musa.
Intl. Network for the Improvement of Banana and Plantain, Montpellier, France.

Simmonds, N.W. and K. Shepherd. 1955. The taxonomy and origins of the cultivated bananas. J. Linn. Soc. London, Botany 55:302-312.

Stambaugh, S.U. 1952. Bananas in Florida. Florida Dept. Agr., Tallahassee.

Stover, R.H. 1987. Somaclonal variation in Grande Naine and Saba bananas in the nursery and field, p. 136-139. In: G.J. Persley and E.A. DeLanghe (eds.). Banana and plantain breeding strategies. Austral. Centre for Intl. Agr. Res. Proc. No. 21.

Stover, R.H. and N.W. Simmonds. 1987. Bananas. $3^{\text {rd }}$ ed. Longmans, London.

Taylor, S.E. and O.J. Sexton. 1972. Some implications of leaf tearing in Musaceae. Ecology 53:143-149

Vakili, N.G. 1967. The experimental formation of polyploidy and its effects in the genus Musa. Amer. J. Bot. 54:24-36. 